Khi tần số cơn co tử cung <2 thì tỷ lệ thành công của Atosiban cắt cớn co tử cung là $96,2 \%$.Khi tần số cơn co bằng 3 thì tỷ lệ thành công của Atosiban cắt cớn co từ cung là $88,3 \%$. Và khi tần số cơn co $>3$ thì tỷ lệ thành công của Atosiban cắt cơn co tò cung chỉ còn $42,8 \%$. Sự khác biệt có ý nghĩa thống kê với $p<0,05$. So sánh với tác dụng của Nifedipin trong nghiên cứu của tác giả Nguyễn Thu Hà thì có 3 trường hợp có cơn co tử cung là 3 trong đó có 2 trường hợp thành công, 2 trường hợp con co TC $=4$ thì đều thất bại, 60 trường hợp có cơn co TC tần số $\leq 2$ thì trong đó có 48 trường hợp thành công chiếm $73,8 \%$. Từ kết quả trên cho thây tần số cơn co TC nhiều hay ít đều có ảnh hưởng đến thời gian cắt được cơn co TC và khả năng kéo dài tuổi thai.

\section{KẾT LUẬN}

Atosiban có hiệu quả điều trị dọa sinh non thời gian duy trì thai kỳ được 48 giờ khá cao $(87,5 \%)$ đây là thời gian cân thiết cho tác dụng tối đa của thuốc trưởng thành phổi. Hiệu quả cắt cơn co đạt được sau >3h dùng Atosiban có tỷ lệ khá cao, bên cạnh đó tỷ lệ điều trị thành công giảm dần theo số lượng cơn co tử cung.

\section{TÀI LIỆ THAM KHẢO}

1. Papatsonis DN, Kok JH, van Geijn HP et al (2000). Neonatal effects of nifedipine and ritodrine for preterm labor. Obstetrics and gynecology, 95(4), 477-481.

2. Ingemarsson I, Lamont RF (2003). An update on the controversies of tocolytic therapy for the prevention of preterm birth. Acta Obstetricia et Gynecologica Scandinavica, 82(1), 1-9.

3. Gyetvai $K$, Hannah ME, Hodnett ED et al (1999). Tocolytics for preterm labor: a systematic review. Obstetrics and gynecology, 94(5 Pt 2), 869-877.

4. Papatsonis D, Flenady V, Cole $S$ et al (2005). Oxytocin receptor antagonists for inhibiting preterm labour. The Cochrane database of systematic reviews, (3), Cd004452.

5. Helmer $\mathbf{H}$, Brunbauer $M$, Rohrmeister $K$ (2003). Exploring the role of Tractocile in everyday clinical practice. BJOG: an international journal of obstetrics and gynaecology, 110 Suppl 20, 113-115.

6. Pham Thi Ngoc Diêp (2010). Đánh giá hiêu quả điêu trị của ATOSIBÁN trong điêu trị dọa sanh nọn tai Bênh viện Từ Dũ. Hôi nội tiết sinh sản và vô sinh thành phố Hồ Chí Minh.

7. Nguyến Hữu Tiến và Lê Lam Hương (2017). Hiệu quả của atosiban trong điều trị dọa sinh non từ 28 đến 34 tuần. Tạp chí Phụ sản, 15(3), 37 - 41.

8. Kashanian M, Akbarian AR, Soltanzadeh M (2005). Atosiban and nifedipin for the treatment of preterm labor. International journal of gynaecology and obstetrics: the official organ of the International Federation of Gynaecology and Obstetrics, 91(1), 10-14.

\title{
KHẢO SÁT NỒNG Độ AMYLASE HUYẾT TƯƠNG Ở BỆNH NHÂN THÂ̂N NHÂN TẠO CHU KỲ TẠI BỆNH VIỆN ĐA KHOA KHU VỰC THỦ ĐỨC
}

\author{
Nguyễn Thị Bé1, Đào Bùi Quý Quyền², Lê Việt Thắng1
}

\section{TÓM TẮT}

Mục tiêu: Xác định nông độ amylase huyết tương ở bệnh nhân bệnh thận mạn giai đoạn cuối thận nhân tao chu kỳ. Đối tượng và phương pháp: Nghiên cứu cắt ngang trên 80 bệnh nhân thận nhân tạo chu kỳ. Tất cả các bệnh nhân được định lượng nồng độ amylase huyết tướng. Kết quả: Nồng độ amylase huyết tương trung bình là $112(92,25-140,75) \mathrm{U} / \mathrm{L}$, có $77,5 \%$ bệnh nhân tăng nồng độ so với tham chiếu.Nồng độ amylase tương quan thuận với nồng độ ure máu, $r=0,303, p<$ 0,01 . Nồng độ creatinine lại là yếu tố độc lập liên quan đến tăng amylase huyết tương, $p<0,05$. Kết luận: Tăng amylase huyết tương là thường gặp và có liên quan đến tăng nồng độ ure và creatinne máu ở bệnh nhân thận nhân tạo chu kỳ.

${ }^{1}$ Học viện Quân y

²Bệnh viện Chơ Rẫy, TPHCM

Chịu trách nhiệm chính: Lê Việt Thắng

Email: lethangviet@yahoo.com.uk

Ngày nhận bài: 5/4/2021

Ngày phản biện khoa học: 8/5/2021

Ngày duyệt bài: 20/5/2021
Tư khóa: Thận nhân tạo chu kỳ, amylase huyết tương, creatinine máu.

\section{SUMMARY \\ SURVEY ON CONCENTRATION OF PLASMA \\ AMYLASE IN THE PATIENTS TREATING WITH MAINTENANCE HEMODIALYSIS AT \\ THU DUC AREA GENERAL HOSPITAL}

Objectives: To determine of plasma amylase levels in patients with end stage chronic kidney disease treating with maintenance maintenance hemodialysis. Subjects and Methods: A cross-sectional study on 80 regular hemodialysis patients. The plasma amylase levels measured in all the patients. Results: The median plasma amylase concentration was 112 (92.25 $140.75) \mathrm{U} / \mathrm{L}$, with $77.5 \%$ of patients increasing the concentration. Amylase concentration was positively correlated with blood urea concentration, $r=0.303$, $p<0.01$. Creatinine concentration was an independent factor associated with increased plasma amylase, $p<0.05$. Conclucsion: Elevated plasma amylase is common and is associated with increased blood urea and creatinine concentrations in patients with regular hemodialysis. 
Keywords: Maintenance hemodialysis, plasma amylase, blood creatinine.

\section{I. ĐặT VẤN ĐỀ}

Lọc máu chu kỳ sử dụng quả lọc và máy lọc (thận nhân tạo chu kỳ-TNTCK) chỉ thay thế được chức năng bài tiết của thận, loại bỏ các chất độc trong máu bệnh nhân, siêu lọc để duy trì trọng lương khô cớ thể, điều chỉnh rối loạn cân bẳng điện giải, chứ không thay thế được chức năng nội tiết của thận như: sản sinh yếu tố kích thích tạo hồng cầu, điều hòa huyết áp, chức năng nội tiết...và không điều trị được nguyên nhân gây bệnh thận [1],[2]. Những bệnh nhân suy thận mạn tính lọc máu chu kỳ ngoài những tổn thương mắc phải do hậu quả suy thận mạn tính gây ra như thiếu máu, tăng huyết áp, bệnh cơ xương khớp... còn có thể mắc thêm bệnh lý của lọc máu chu kỳ dài ngày như: nhiễm các bệnh lâyy truyền qua đường máu, viêm, suy dinh dưỡng... Tăng nồng độ amylase cũng là một biểu hiện thường gặp ở bệnh nhân bệnh thận mạn tính giai đoạn cuối lọc máu chu kỳ. Việc định lượng amylase trong huyết thanh phổ biến ở các cở sở điều trị trên các bệnh nhân nghi ngờ viêm tự, tuy nhiên ở bệnh nhân suy thận mạn theo nhiều nghiên cứu cho thấy amylase máu tăng do mức lọc cầu thận giảm mà không có viêm tụy [3],[4]. Vì vậy, bệnh nhân bệnh thận mạn khi có triệu chứng viêm tụy cấp, xét nghiệm amylase máu trở nên khó đánh giá.Xuất phát từ những lý do trên, chúng tôi thực hiện đề tài này với mục tiêu: Khảo sát nồng độ amylase huyêt tương ở bệnh nhân thận nhân tạo chu kỳ tại Bệnh viện đa khoa khu vực Thủ Đức.

\section{II. ĐỐI TƯợNG VÀ PHƯƠNG PHÁP NGHIÊN CỨU}

1. Đối tượng nghiên cứu: Đối tượng là80bệnh nhân bệnh thận mạn tính (BTMT) giai đoạn cuối được lọc máu bằng thận nhân tạo chu kỳ, tại Khoa Thận tiết niệu, Bệnh viện đa khoa khu vực Thủ Đức. Thời gian nghiên cứu từ tháng 4/2020 đến tháng 4/2021.

\section{-Tiêu chuẩn chơn bệnh nhân:}

+ Bệnh nhân bệnh thận mạn tính giai đoạn cuối lọc máu bằng TNTT chu kỳ

+ Thời gian lọc máu $>3$ tháng.

+ Các bệnh nhân được lọc máu đủ tuân 3 lần, mỗi lần 4 giờ, đảm bảo hiệu quả lọc $\mathrm{Kt} / \mathrm{V}>1,2$.

+ Các bệnh nhân đều được áp dụng theo một phác đồ điểu trị thống nhất về chế độ lọc máu, điều trị thiếu máu, điều trị tăng huyết áp...

+ Bệnh nhân đồng ý tham gia nghiên cứu

- Tiêu chuấn loại trừ bênh nhân:

+ Bệnh nhân tại thời điểm nghiên cứu nghi ngờ mắc bệnh ngoại khoa.

+ Bệnh nhân viêm nhiễm nặng như viêm phổi, viềm tuy cấp....

+ Các bệnh nhân không đủ tiêu chuẩn nghiên cứu.

\section{Phương pháp nghiên cứu}

- Nghiên cứu mô tả, cắt ngang nhóm bệnh nhân nghiên cứu.

- Tính cõ mẫu theo công thức:

$$
\mathrm{N}=\frac{\left(Z_{1-\mathrm{a} / 2)^{2} \times \mathrm{p}(1-\mathrm{p})}\right.}{\mathrm{D}^{2}}
$$

Trong đó: $Z=1,96$, với độ tin cậy là $95 \%$ $\mathrm{p}=0,78$ (giá trị thấp nhất tỷ lệ ở các nghiên cứu trước)

$\mathrm{D}=0,1$, độ chính xác mong muốn.

Theo cách tính, tối thiểu nghiên cứu phải có 55 bệnh nhân.Trong nghiên cứu chúng tôi có 80 bệnh nhân đủ tiêu chuẩn nghiên cứu.

-Bệnh nhân được hỏi bệnh sử, khám lâm sàng. Các xét nghiệm cận lầm sàng bao gồm: xét nghiệm công thức máu, sinh hoá máu các chỉ số: glucose, ure, creatinine, albumin, protein...

-Định lượng nồng độ amylase huyết tương: bằng phương pháp enzyme, đánh giá tăng nồng độ dựa vào hướng dẫn của Labo thực hiện xét nghiệm (> 90 UI/L).

3. Xử lý số liệu: Số liêu được xử lý bằng thuật toán thống kê y sinh học theo chương trình SPSS 20.0

\section{KẾT QUẢ NGHIÊN CỨU}

Tuổi trung bình $53,55 \pm 14,72$, tỷ lệ nam là $45,0 \%$, nữ chiếm $55,0 \%$. Nhóm nghiên cứu có thời gian TNT trung bình là $46(13-76)$ tháng. Nồng độ amylase huyết tương trung bình là 112 $(92,25-140,75) \mathrm{U} / \mathrm{L}$, nhỏ nhất là $36 \mathrm{U} / \mathrm{L}$, lớn nhất là $318 \mathrm{U} / \mathrm{L}$.

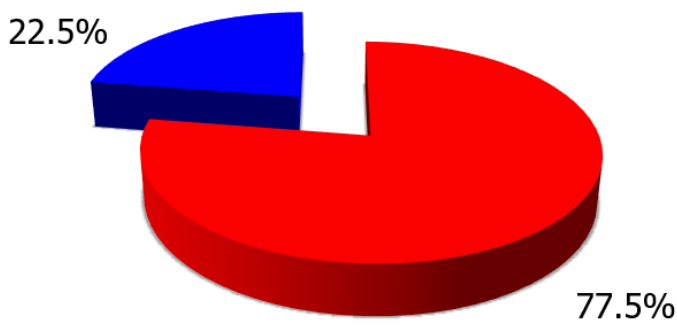

- Tăng amylase - Không tăng

Biểu đồ 1.Tỷ lệ bệnh nhân tăng amylase huyêt tương $(n=80)$

Nhận xét: Tăng amylase huyết tương là thường gặp ở bệnh nhân TNT, tỷ lệ tăng trong nghiên cứu này là $77,5 \%$. 
Bảng 1. Liên quan nồng độ amylase huyết tương với tuổi và giới

\begin{tabular}{|c|c|c|c|}
\hline \multicolumn{2}{|c|}{ Đăc điếm } & Số bênh nhân & Tỷ lệ (\%) \\
\hline \multirow{2}{*}{ Nữ $(n=44)$} & Tăng & 33 & 75,0 \\
\hline & Trung vị (Tứ phân vi) & \multicolumn{2}{|c|}{$109(87,25-144,25)$} \\
\hline \multirow{2}{*}{$\operatorname{Nam}(n=36)$} & Tăng & 29 & 80,6 \\
\hline & Trung vị (Tứ phân vị) & \multicolumn{2}{|c|}{$113(93,25-140)$} \\
\hline \multicolumn{2}{|r|}{$\mathrm{p}$} & \multicolumn{2}{|c|}{$>0,05$} \\
\hline \multirow{2}{*}{$\geq 60$ tuổi $(n=31)$} & Tăng & 21 & 67,7 \\
\hline & Trung vị (Tứ phân vị) & \multicolumn{2}{|c|}{$96(75-121)$} \\
\hline \multirow{3}{*}{$<60$ tuổi $(n=49)$} & Tăng & 41 & 83,7 \\
\hline & Trung vị (Tứ phân vị) & \multirow{2}{*}{\multicolumn{2}{|c|}{$119(96-144)$}} \\
\hline & $\mathrm{p}$ & & \\
\hline
\end{tabular}

Không có mối liên quan nồng độ amylase huyết tương với giới, tuy nhiên bệnh nhân tuối cao có nồng độ amylase thấp hơn nhóm tuổi $<60$ có ý nghĩa, p< 0,05.

Bảng 2. Liên quan với thời gian thận nhân tạo

\begin{tabular}{|c|c|c|c|}
\hline \multicolumn{2}{|c|}{ Đặc điếm } & Số bệnh nhân & Tỷ lệ (\%) \\
\hline \multirow{2}{*}{ < 5 năm $(\mathrm{n}=51)$} & Tăng & 39 & 76,5 \\
\hline & Trung vị (Tứ phân vị) & \multicolumn{2}{|c|}{$113(91-146)$} \\
\hline \multirow{2}{*}{$\begin{array}{c}5 \text { đến }<10 \text { năm } \\
(\mathrm{n}=20)\end{array}$} & Tăng & 16 & 80,0 \\
\hline & Trung vị (Tứ phân vị) & \multicolumn{2}{|c|}{$103(92,25-135,25)$} \\
\hline \multirow{2}{*}{$\geq 10$ năm $(n=9)$} & Tăng & 7 & 77,8 \\
\hline & Trung vị (Tứ phân vị) & \multicolumn{2}{|c|}{$118(88,5-171,5)$} \\
\hline
\end{tabular}

Không có mối liên quan nồng độ amylase huyết tương với thời gian TNT chu kỳ.

Bảng 3. Tương quan nồng độ amylase với ure và creatinine máu

\begin{tabular}{|c|c|c|c|}
\hline \multirow{2}{*}{ Chỉ số } & \multicolumn{2}{|c|}{ Amylase (U/I) } & \multirow{2}{*}{ Phương trình tương quan } \\
\cline { 2 - 3 } & $\mathrm{r}$ & $\mathrm{p}$ & \\
\hline Ure $(\mathrm{mmol} / \mathrm{l})$ & 0,303 & $<0,01$ & Amylase $=1,885 *$ Ure $+72,472$ \\
\hline Creatinine $(\mu \mathrm{mol} / \mathrm{l})$ & 0,175 & $>0,05$ & - \\
\hline
\end{tabular}

Chỉ thấy mối tương quan giữa nồng độ amylase với nồng độ ure máu ở bệnh nhân TNT chu kỳ, $p<0,05$.

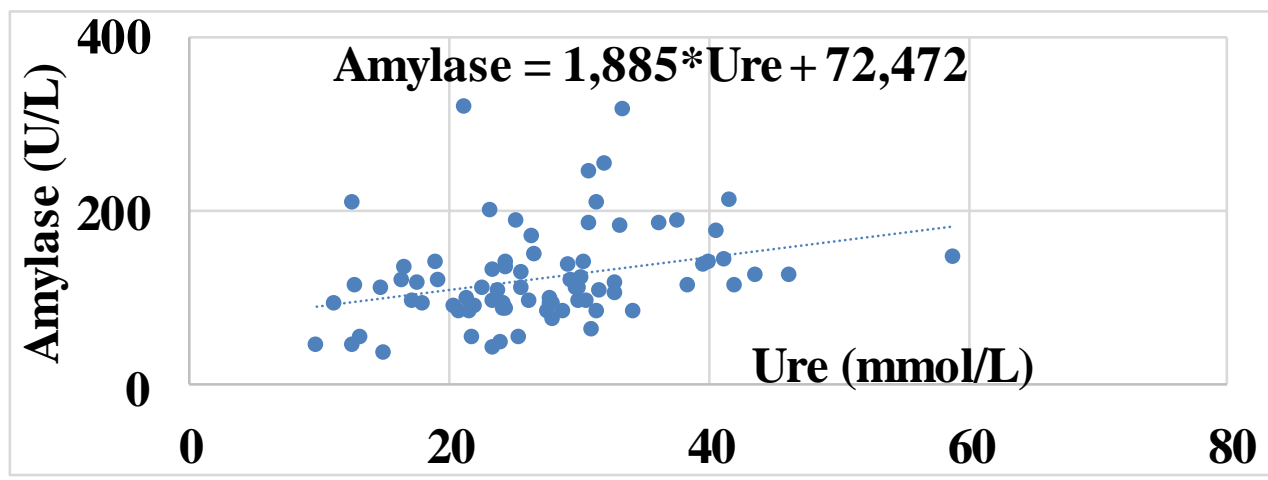

Biểu đồ 2.Tương quan giữa Amylase và Ure máu ( $n=80)$

Nhận xét: Có mối tương quan thuận giữa nồng độ amylase và nồng độ ure máu có ý nghĩa, $r=0,303, p<0,05$.

Bảng 4. Hối quy logistic các yêu tốnguy cơ tăng amylase máu

\begin{tabular}{|c|c|c|c|}
\hline Yếu tố & Odds ratio (OR) & Khoảng tin cậy 95\% & P \\
\hline Giới nam & 0,879 & $0,248-3,119$ & $>0,05$ \\
\hline Thời gian lọc máu $\geq 10$ năm & 0,662 & $0,099-4,413$ & $>0,05$ \\
\hline BMI $\geq 23$ & 0,885 & $0,164-4,763$ & $>0,05$ \\
\hline Rối loạn lipid máu & 0,652 & $0,178-2,392$ & $>0,05$ \\
\hline Albumin < 35 g/l & 0,409 & $0,095-1,765$ & $>0,05$ \\
\hline Nhiêm virus viêm gan & 2,531 & $0,438-14,636$ & $>0,05$ \\
\hline
\end{tabular}


VIETNAM MEDICAL JOURNAL N ${ }^{0} 1$ - JUNE - 2021

\begin{tabular}{|c|c|c|c|}
\hline ĐTÐ & 0,630 & $0,146-2,719$ & $>0,05$ \\
\hline Creatinine & 1,003 & $1,000-1,005$ & $<0,05$ \\
\hline
\end{tabular}

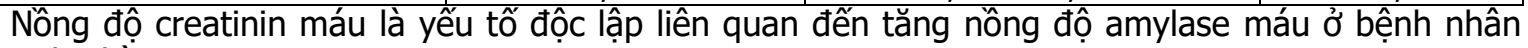
TNT chu kỳ, $p<0,05$.

\section{BÀN LUÂN}

1. Đặc điểm nồng độ amylase huyết tương ở bệnh nhân nghiên cứu: Tất cả các nghiên cứu đều cho thấy tăng amylase là phổ biến ở bệnh nhân BTMT nói chung, bệnh nhân TNT chu kỳ nói riêng và tỷ lệ tăng hầu hết các nghiên cứu đều công bố > 70\%.

Bảng 5. So sánh nồng độ amylase huyêt tương các nghiên cứu

\begin{tabular}{|c|c|c|c|}
\hline Tác giả & Đối tượng & Tỷ lệ tăng & $\begin{array}{c}\text { Nồng độ trung } \\
\text { bình (UII/L) }\end{array}$ \\
\hline $\begin{array}{l}\text { Jiang C.F. và } \\
\text { cộng sự năm } \\
2002 \text { [7] }\end{array}$ & $\begin{array}{l}\text { - } 49 \text { BN lọc máu chu kỳ trong đó có: } 37 \text { BN TNT } \\
\text { và } 12 \text { BN lọc màng bụng } \\
\text {-Chẩn đoán tăng amylase huyết tương: từ } 80 \text { UI/L }\end{array}$ & $\begin{array}{l}\text {-Nhóm LMB: } \\
\text { 66,7\% } \\
\text {-TNT: } 83,7 \% .\end{array}$ & - \\
\hline $\begin{array}{l}\text { Lee S.Y. và } \\
\text { cộng sự năm } \\
2005 \text { [5] }\end{array}$ & $\begin{array}{l}\text { - } 344 \text { BN bệnh thận mạn trong đó: } 73 \text { bệnh nhân } \\
\text { điêu trị nội khoa, } 105 \text { BN TNT chu kỳ và } 71 \text { BN } \\
\text { sau ghép thận. }\end{array}$ & - & $\begin{array}{c}93,7 \pm 76,5 \\
\text { UI/L }\end{array}$ \\
\hline \begin{tabular}{|c|}
$\begin{array}{c}\text { Pal A. và cộng } \\
\text { sự năm } 2018 \\
{[6]}\end{array}$ \\
\end{tabular} & $\begin{array}{l}\text { - } 128 \text { BN bênnh thận mạn giai đoạn 3-5 trong đó } \\
\text { mối nhóm giai đoạn là } 42 \text { bệnh nhân. } \\
\text { - Chẩn đoán tăng amylase huyết tương từ } 80 \text { UI/I }\end{array}$ & $\begin{array}{c}\text { Tỷ lệ tăng nhóm } \\
\text { BN giai đoạn } 5 \text { là } \\
76,2 \%\end{array}$ & - \\
\hline \begin{tabular}{|c|} 
Lê Quang Hải \\
và cộng sự năm \\
2017 [7] \\
\end{tabular} & $\begin{array}{l}\text { - } 108 \text { bệnh nhân bệnh thận mạn giai đoạn } 5 \text { trong } \\
\text { đó có } 57 \text { BN TNT chu kỳ. } \\
\text { - Chẩn đoán tăng amylase từ } 90 \text { UI/L trở lên }\end{array}$ & $\begin{array}{l}\text { Tỷ lệ tăng là } \\
78,9 \%\end{array}$ & \\
\hline Chúng tôi 2021 & $\begin{array}{l}\text { - } 80 \text { bệnh nhân bệnh thận mạn giai đoạn cuối } \\
\text { TNT chu kỳ. } \\
\text { - Chẩn đoán tăng khi amylase huyết tương từ } 90 \\
\text { UI/l trở lên. }\end{array}$ & $\begin{array}{l}\text { Tỷ lệ tăng là } \\
77,5 \%\end{array}$ & $\begin{array}{c}112(92,25- \\
140,75)\end{array}$ \\
\hline
\end{tabular}

Thận giảm chức năng, dẫn đến đào thải amylase không được gây ứ lại amylase máu, đây là lý do chính dẫn đến tăng amylase máu ở bệnh nhân BTMT [5],[6]. Chính vì vậy, tăng amylase máu ở bệnh nhân BTMT thường không kèm theo biểu hiện viêm tụy hoặc tuyến nước bọt. Mức độ tăng amylase máu không cao so với những tổn thương cấp tính tại tụy như viêm tụy, hoại tử tuyến...Nguyên nhân thứ nữa dẫn đến tăng amylase máu chính là nuôi dưỡng tại tuyến tụy kém do vôi hóa mạch máu và tuyến. Những tổn thương tại tuyến này sẽ trở thành yếu tố kích thích viêm không nhiễm khuẩn, phần viêm của tuyến sẽ tăng tiết amylase máu.Bệnh nhân BTMT giai đoạn cuốithường có biểu hiện rối loạn lipid máu (tăng triglycerid), đây cũng là một nguyên nhân gây tăng tiết amylase máu ở những bệnh nhân suy thận mạn tính.Tăng các hormon tiêu hóa khác nhau như cholecystokinin, polypeptid ức chế dạ dày và glucagon ở bệnh nhân BTMT có thể kích thích tăng tiết các enzym tuyến tụy như trypsin có thể góp phần làm suy giảm chức năng tuyến tụy.

2. Liên quan nồng độ amylase với môt số đặc điểm bệnh nhân: Kết quả nghiên cứu cho thấy tăng amylase máu không liên quan đến giới, thời gian thận nhân taoo, tuy nhiên có mối tương quan thuận giữa nồng độ amylase máu và nồng độ ure máu $r=0,303, p<0,05$. Ở bệnh nhân viêm tuy. cấp, tình trạng tăng ure và creatinine có ý nghĩa tiên lượng bệnh, đặc biệt bênh nhân viêm tuy cấp nặng, tăng cao amylase và lipase máu.Có rất nhiều cơ sở, dựa vào đó ure máu đã được chọn làm tiên lượng về diễn biến viêm tuỵ cẩp [8].Nồng độ ure lúc nhập viện có thể phản ánh tình trạng sinh lý cơ bản của bệnh nhân, bao gồm suy giảm thể tích nội mạch và tăng ure huyết ngoài thận. Thứ hai, sự gia tăng liên tục hoặc sự gia tăng sau đó của ure có thể phản ánh sự thất bại trong việc hồi sức đầy đủ cho bệnh nhân sớm trong giai đoạn bệnh của ho, suy giảm chức năng thận hoặc tình trạng cân bằng nitơ âm liên tục liên quan đến tăng dị hóa protein do viêm tuỵ cấp gây ra. Thứ ba, người ta cho rằng, mặc dù không có dấu hiệu lâm sàng của viêm tụy và thay đổi hình ảnh tuy, sự dao động của ure đặc biệt dễ xuất hiện do thiếu máu cục bộ của tụy. Bên cạnh ảnh hưởng của các enzym tuyến tựy, các yếu tố gây viêm có thể gây rối loạn chức năng thận thông qua rối loạn chức năng tim, trụy tuần hoàn, giảm tưới máu, nhiễm toan chuyển hóa, sốc và tạo ra hội chứng suy hô 
hấp cấp tính. Tuy nhiên, ở bệnh nhân của chúng tôi giải thích bởi sự gia tăng ure có liên quan đến quá trình lọc máu chưa thực sự tốt gây các rối loạn trong đó có rối loạn tiết tuy ngoại tiết.Trong nghiên cứu này chúng tôi nhận thấy tăng creatinine máu liên quan độc lập với tăng amylase máu và giảm albumin độc lập liên quan với xuất hiện rối loạn dạ dày ruột. Tăng amylase máu là phổ biến ở bệnh nhân BTMT nói chung, bênh nhân TNT chu kỳ nói riêng. Ở bênh nhân BTMT giai đoạn cuối có nhiều yếu tố liên quan đến tăng nồng độ amylase máu trong đó có giảm mức lọc câu thận [6],[7]. Kết quả nghiên cứu của chúng tôi khẳng định creatinine một lân nữa giảm chức năng thận, không đào thải được amylase qua đường niệu là nguyên nhân chủ yếu gây tăng amylase máu.

\section{KẾT LUÂNN}

-Nông độ amylase huyết tương trung bình là $112(92,25$ - 140,75) U/L, có 77,5\% bệnh nhân tăng nồng độ.

- Nồng độ amylase tương quan thuận với nồng độ ure máu, $r=0,303, p<0,01$. Nồng độ creatinine lại là yếu tố độc lập liên quan đến tăng amylase huyết tương.

\section{TÀI LIÊU THAM KHẢO}

1. Nguyễn Hữu Dũng, Đỗ Gia Tuyển (2021).
Điều trị thay thế thận suy bằng thận nhân tạo chu kỳ. Bệnh học nội khoa thận tiết niệu. Nhà xuất bản Y hoc tâp2: 225-244.

2. Lê Viêtet Thắng (2019). Chẩn đoán và điêu trị môt số bệnh câu thận, khe ống thận. Cập nhật chẩn đoán, điều trị và dự phòng một số bệnh thận. Hoc viện Quân y: 83,86-98.

3. Chen YH, Yang WC, Wang FM, et al. (2011). Risk factors associated with elevated serum pancreatic amylase levels during hemodialysis. Hemodial Int.2011 Jan 12, [Epub ahead of print].

4. Jiang CF, Ng KW, Tan SW, et al. (2002).Serum level of amylase and lipase in various stages of chronic renal insufficiency. Zhonghua Yi Xue Za Zhi (Taipei). 65(2): 49-54.

5. Lee SY, Lee KT, Kang TW, et al. (2005). Pancreatic enzyme elevations in Korean chronic renal failure patients. Korean J Gastroenterol. 45(2): 125-9.

6. Pal A, Mandal L. (2018). Serum Amylase in Patients of Chronic Kidney Disease Stage Three to Stage Five. Birat Journal of Health Sciences, 3(2), 403-407.

7. Lê Quang Hải, Nguyễn Hữu Dũng, Nguyễn Thị Thu Hương và cộng sự (2017). Khảo sát nồng độ amylase huyết thanh ở bệnh nhân bệnh thận mạn tính giai đoạn cuối. Tạp chí Y Dược lâm sàng 108 , tâp 12 số $5:$ 36-41.

8. Pando E, Alberti $P$, Mata $R$, et al. (2021). Early Changes in Blood Urea Nitrogen (BUN) Can Predict Mortality in Acute Pancreatitis: Comparative Study between BISAP Score, APACHE-II, and Other Laboratory Markers-A Prospective Observational Study. Can J Gastroenterol Hepatol. eCollection.

\section{NHẬN XÉT ĐĂC ĐIỂM TỔN THƯƠNG GIẢI PHẪU GÃY LIÊN MẤU CHUYỂN XƯƠ'NG ĐÙI TRÊN HİNH ẢNH CHỤP CẮT LỚP VI TÍNH}

\section{TÓM TẮT}

Mục tiêu: Đánh giá chính xác tổn thương giải phẫu đóng vai trò quan trọng trong xây dựng kế hoạch điều trị phẫu thuật gãy liên mấu chuyển xương đùi. Đối tượng và phương pháp: Gồm 101 bệnh nhân gãy liên mấu chuyển xương đùi được phân lioại tổn thương giải phẫu dựa trên $X$ quang theo phân loại của $A O$ và phân loại theo Etsuo dựa trên hình ảnh $C T$ $3 D$. Tìm hiểu mức độ phù hợp của phân loại theo $A O$ dựa trên $X$ quang so với phân loại theo Etsuo dựa trên hình ảnh CLVT. Kết quả: Kết quả nghiên cứucho thấy gãy liên mấu chuyển xương đùi tồn tại 3 đường gãy chính: đường gãy ở phía trước gặp ở 101 trường hợp

\footnotetext{
*BV Đa khoa vưng Tây Nguyên

**Hoc viên Quân Y

Chịu trách nhiệm chính: Lê Tất Thắng

Email: phamdangninh103@gmail.com

Ngày nhận bài: 4/4/2021

Ngày phản biện khoa học: 1/5/2021

Ngày duyệt băi: $18 / 5 / 2021$
}

\section{Lê Tất Thắng*, Đặng Hoàng Anh**}

(100\%), đường gãy ở phía sau gặp ở 92 trường hợp $(91,09 \%)$ và đường gãy ở phía ngoài gặp ở 53 trường hợp (52,47\%). Phân loại theo Etsuo gồm: gãy 2 phân chiếm $19,80 \%$, gãy 3 phần chiếm $72,28 \%$ và gãy 4 phần chiếm 7,92\%. Gãy 3 phần loại chỏm - mấu chuyển lớn + mấu chuyển bé +thân xương chiếm tỷ lệ cao nhất $(41,10 \%)$. Trong 41 trường hợp gãy 2 phần trên $X$ quang qui ước, chụp CLVT dựng hình $3 \mathrm{D}$ phát hiện 21 trướng hợp gãy 3 phần. Kết quả nghiên cứu ghi nhận có sự phù hợp kém về phân loại theo số phân gãy giữa XQ và CLVT với $K=0,405$. Kết luận: Phân loại gãy liên mấu chuyển dựa trên phim $X$ quang có sự hạn chế về độ chính xác. Hình ảnh chụp CLVT có dựng hình $3 \mathrm{D}$ đã được chứng minhlà chính xác cao hơn do phát hiện đây đủ hơn về vị trí, hình thái các đường gãy và số lượng mảnh gãy

Ti̛ khóa: Cắt lớp vi tính, gãy liên mấu chuyển, $X$ quang.

\section{SUMMARY \\ EVALUATION OF CHARACTERISTICS OF ANATOMICAL INJURIES OF}

